A comparison between Dutch and German retail price setting

den Hertog, Rene G J; Thurik, A Roy

The Service Industries Journal; Jan 1995; 15, 1; ABI/INFORM Global

pg. 66

\title{
A Comparison between Dutch and German Retail Price Setting
}

\author{
RENÉ G.J. DEN HERTOG and A. ROY THURIK
}

This article examines the differences between Dutch and German retail price setting. The study is based on an econometric approach in the sense that the estimates of the coefficients of a one-equation model explaining retail profit margins are compared. Extensive datasets are used for both the Dutch and German case, allowing a general comparison between the two countries to be made. An ex post interpretation of the differences in coefficients found is given.

\section{INTRODUCTION}

In the literature the general topic of retail price setting has not received extensive attention. In the marketing literature the interest in retailing is growing [Berry, Gresham and Millikin, 1990], but so far attention to the narrower topic of pricing in retailing has focused mainly on specific products, shops or consumer segments or upon specific promotional situations. ${ }^{1}$ In the industrial organization literature there is also a lack of studies attempting to explain retail behaviour. Particularly in the area of price setting, theoretical and empirical studies tend to concern manufacturing [Cubbin, 1988; Schmalensee, 1989].

The limited orientation towards retailing may be the result of the considerable differences between retailing and manufacturing. ${ }^{2}$ Straightforward differences are product and market. The 'product' of retailing is a 'bundle of services' with several dimensions, such as price level, proximity, accessibility, assortment width and depth [Hall, Knapp and Winsten, 1961]. Retailing does not offer a clearly defined product. The market of retail services is inherently imperfectly competitive and in this market conditions of (spatial) oligopoly

R.G.J. den Hertog is at the Tinbergen Institute, Erasmus University Rotterdam, Oostmaaslaan 950-952, 3063 DM Rotterdam, the Netherlands.

A.R. Thurik is at the Centre for Advanced Small Business Economics, Erasmus University

Rotterdam and EIM Small Business Research and Consultancy, PO Box 7001, 2701 AA

Zoetermeer, the Netherlands.

The Service Industries Journal, Vol. 15, No. 1 (January 1995), pp.66-73

PUBLISHED BY FRANK CASS, LONDON 
may arise [Hall, 1949].

The lack of studies attempting to compare the retail price setting of different countries is even greater. We know of only two studies: Den Hertog, Potjes and Thurik [1994] and Nooteboom, Thurik and Vollebregt [1988]. ${ }^{3}$ The lack of appropriate data usually hampers studies with an international dimension. Nooteboom, Thurik and Vollebregt [1988] deal, for instance, with only one year and a limited number of shop types. In the present study we shall try to fill the gap in studies of retail price setting from an international perspective by comparing the Dutch and German situation. For the two countries, data are used for the same period, 1981-86, and the same 21 shop types. The shop types cover almost completely the entire spectrum of shop types across retailing. This allows a comparison between the retail trade of the two countries as a whole.

Instead of presenting anecdotal evidence on possible differences in retail price setting between the Netherlands and Germany, we shall start with an empirical analysis of the retail price setting of both countries in order to determine the differences. Once the differences have been identified, we will give a more specific explanation of them. We shall follow an econometric approach in the sense that the analysis of the differences in retail price setting will be based on the estimates of the coefficients of a one-equation model, which explains retail profit margins for the Netherlands and Germany separately. The equation is the full average cost pricing model presented in Nooteboom [1985]. The model explains the average percentage gross margin as an average percentage profit mark-up on average percentage operating costs excluding a reward for shopkeepers' labour. 'The mark-up is composed of four elements that represent a scale effect, a shop type effect, a life cycle effect and a business cycle effect. The model has also been used to analyse structural changes in retailing such as increasing scale, concentration and declining share of independents and their causes [Nooteboom, 1986], and to explain differences in profit between small and large scale manufacturing [Thurik and Van der Hoeven, 1989].

The structure of the current study is as follows: the second section presents the model; the data are described in the third; and the fourth discusses the results.

\section{MODELLING RETAIL PROFIT MARGINS}

According to Nooteboom [1985:647], his model explains differences in retail profit margins between different shop types as well as the development in time per type of shop. His model has been used in various studies. ${ }^{5}$ In the mark-up model the average percentage gross margin, $M$, is modelled as an additive function of the percentage operating costs, $K,{ }^{\circ}$ a constant term and 
four variables that account for a scale effect, a shop type effect, a life cycle effect and a business cycle effect. Both the margin and the costs are expressed as a percentage of sales.

According to Nooteboom, the percentage profit mark-up is inversely related to the sales size of a shop, because a higher sales size allows a lower percentage of sales to achieve a given minimum reward for the shopkeeper. This scale effect is accounted for by ratio of the consumer price index, $P$, to the sales size, $Q$. The shop type effect implies that a more varied range of products and a higher service level require a higher percentage profit mark-up to achieve a given return on investment. Nooteboom [1985] uses income elasticity of products and services offered to determine the importance of the shop type effect. Nooteboom, Kleijweg and Thurik [1988] have, however, shown that the stock level, that is defined as the stock as a percentage of sales, $V / Q$, appears to be a better indicator than the income elasticity. The underlying idea is that a high stock level often accompanies a deeper and wider range of products and hence a higher service level. A deeper and wider range of products also means more uncertainty, for which the retailer requires a compensating premium.

The underlying idea of the life cycle effect is that the margin depends on the phase of the life cycle of the shop type: during the penetration phase there is a bonus on novelty, during the phase of saturation this bonus disappears; and during the phase of decline the profit mark-up shrinks due to heavy competition of new types of trade. The mark-up model of Nooteboom [1985] contains the change in market share of the shop type to account for the life cycle effect. In the current study this variable had to be dropped because no data are available. The growth of consumer spending (in volume), CCS, accounts for the dependence of the profit margins on the economic situation, that is, the business cycle effect. Price competition is assumed to become more intense in a contracting market because retailers attempt to sustain sales volume.

In the current study, the mark-up relationship is

$$
M_{i t}=a_{0}+a_{1} K_{i t}+a_{2} P_{t} / Q_{i t}+a_{3} V_{i t} / Q_{i t}+a_{4} C C S_{i t}+u_{i t}
$$

for shop type $i$ and year $t$, where $u$ is the error. If percentage gross margins are indeed a percentage profit mark-up on the percentage operating costs, the coefficients $a_{0}$ and $a_{1}$ should be zero and one, respectively. However, in Nooteboom, Kleijweg and Thurik [1988] $a_{0}$ was found to be significantly different from zero. From the discussion above, we know that the coefficients $a_{2}$, $a_{3}$ and $a_{4}$ should be positive. It can be shown that the coefficient $a_{2}$ represents a net profit level which is independent of the characteristics of the shop type. Nooteboom [1985] and Nooteboom, Kleijweg and Thurik [1988] report esti- 
mates for $a_{2}$ close to the legal minimum wage for employees.

The above approach is classified by industrial economists as belonging to the behaviourial theories. These theories represent the view that optimising behaviour is not the key issue in a world of uncertainties, irrationalities and misty simultaneous and collective decision making [Waterson, 1984].

DATA

Both the Dutch and German data are used for the period 1981-86 (6 years) for 21 shop types, yielding a total of 126 observations. For the profit margins, the operating costs, sales and stock level the data are the average values for the shop types. For Germany our main data-source is Sundhoff and KleinBlenkers [1982-87]. The German price index used to compute P/Q is taken from the International Financial Statistics of the IMF (yearbook 1987). The data on the growth of consumer spending are based on data of the National Accounts of the OECD.

For the Netherlands, the data-source is an ongoing panel of independent, mainly small Dutch retailers called 'Bedrijfssignaleringssysteem' (firm signalling system), which is operated by the Research Institute for Small and Medium-Sized Business (EIM) in Zoetermeer, the Netherlands. The data on the Dutch price index and the growth of consumer spending were gathered by the Central Bureau of Statistics (CBS) in Voorburg, the Netherlands. The data were elaborated by the EIM.

The 21 shop types are presented in Table 1. One can see that they practically span the entire spectrum of shop types retailing in Germany and the Netherlands. Food shop types are underrepresented.

TABLE 1

A SURVEY OF THE SHOP TYPES

\begin{tabular}{|c|c|}
\hline Groceries & Lighting and electric \\
\hline Tobacco shop & Floor-covering and wallpaper \\
\hline Clothes shop: men and children & Chemist's shop \\
\hline Clothes shop: women and children & Photographer's shop \\
\hline Clothes shop: men, women and children & Jeweller's shop \\
\hline Clothes shop: mixed assortment & Cycle shop \\
\hline Bed-clothes & Sports shop \\
\hline Shoe shop & Bookshop \\
\hline Furniture store & Florist's shop \\
\hline $\begin{array}{l}\text { House and kitchen utensils } \\
\text { Iron tools }\end{array}$ & Toys \\
\hline
\end{tabular}


TABLE 2

ESTIMATION RESULTS

\begin{tabular}{|c|c|c|c|c|c|}
\hline & Constant & $\mathbf{K}$ & $\mathrm{P} / \mathrm{Q}$ & $\mathrm{V} / \mathrm{Q}$ & $\mathrm{CCS}$ \\
\hline Netherlands & $\begin{array}{c}2.466^{*} \\
(0.751)\end{array}$ & $\begin{array}{r}1.078 * \\
(0.027)\end{array}$ & $\begin{array}{l}13.208^{*} \\
(2.603)\end{array}$ & $\begin{array}{c}0.031^{*} \\
(0.015)\end{array}$ & $\begin{array}{r}0.150^{*} \\
(0.025)\end{array}$ \\
\hline Germany & $\begin{array}{r}1.693^{*} \\
(0.855)\end{array}$ & $\begin{array}{c}0.969^{*} \\
(0.029)\end{array}$ & $\begin{array}{c}20.802^{*} \\
(2.679)\end{array}$ & $\begin{array}{c}0.040^{*} \\
(0.009)\end{array}$ & $\begin{array}{l}-0.041 \\
(0.065)\end{array}$ \\
\hline F-test & 0.720 & $11.751^{*}$ & 3.994* & 0.350 & $8.966^{*}$ \\
\hline
\end{tabular}

\section{EMPIRICAL RESULTS}

Dutch and German data are available for the same set of shop types and the same period. This allows us to use the method of Seemingly Unrelated Regressions (SUR). SUR accounts for the correlation between the residuals of the two countries [Judge et al., 1985]. This method has two important advantages. First, SUR provides more efficient estimates of the coefficients. Secondly, an F test of the hypothesis that there is no difference in the coefficient between the two countries can be calculated for each explanatory variable. The results are presented in Table 2 .

The results indicate no significant differences in the intercept and the coefficient of the stock level between the Netherlands and Germany. ${ }^{7}$ For both countries the intercept is positive and significantly different from zero. Since the intercept determines the direct relation between sales size and net profits, the results suggest that an increase of scale has a direct positive effect on net profits in the Netherlands as well as in Germany. The service level, represented by the stock level, has a significant, positive effect on both Dutch and German retail profit margins. The customers of both countries seem to be prepared to pay not only the higher operating costs resulting from a higher stock level but also a bonus for more service. ${ }^{8}$

The $\mathrm{F}$ tests indicate significant differences between the coefficients of the costs, $K$, the inverse of deflated sales, $P / Q$, and the growth of consumer spending, CCS, for the Netherlands and those for Germany. These differences can be explained by the difference in firm size between the two countries. The average shop is smaller in the Netherlands than in Germany. Ravesloot and Vogelesang [1989] report average sales of 291 and 552 thousand ECU in 1986 for Dutch and German firms, respectively. Average sales calculated from our data show the same difference. The difference in firm size may be a result of the Dutch government's restrictive policy with respect to hypermarkets and other large scale stores in peripheral areas. 
The difference between the coefficients of the costs, 1.08 for the Netherlands and 0.97 for Germany, may be the result of the difference in firm size. The way in which retailers pass on their operating costs reflects the amount of risk they are prepared to take. ${ }^{9}$ The owners of small firms have less financial resources to take care of financial problems resulting from unexpected increases in costs or unexpected lower sales volumes. Moreover, these owners usually need to generate a family income. For both reasons, they do not want to take much risk and pass on even more than 100 per cent of their costs to their customers.

The difference in firm size is also consistent with the different coefficients of the inverse of sales. As mentioned in the second section, the coefficient of this variable reflects a net profit level independent of the shop type characteristics. It is comprehensible that this basic profit level is lower for a country of which retailing's average firm size is lower. Given the definition of the variables, we find a basic profit level of about 13,200 Dutch guilders for the Netherlands and 20,800 DM for Germany at 1976 prices. ${ }^{10}$ These estimated values are close to the minimum wages of both countries.

It is also interesting to see that the small Dutch firms are more sensitive to changes in economic conditions than the large German firms. In contracting markets small firms may find it more difficult to sustain their sales volume, and therefore they need to reduce their profit margins more than large firms. In growing markets small firms seem to be able to exploit the market opportunities better, ie., the prices of small firms can increase more than the prices of large firms.

\section{CONCLUSIONS}

Comparing the retail price setting of the Netherlands and Germany, one does not expect many differences a priori. The two countries have a common border and their economic differences are small. Remaining differences are eliminated by the continuing integration within the European Union. We have, however, found differences in the effect of operating costs and growth of consumer spending on retail profit margins and different basic rewards. We argue that it is the variations in average firm size that may cause these disparities in retail price setting between the Netherlands and Germany. It is not unrealistic to assume that the difference in firm size may also cause variations in other marketing practices between the two countries, and may also explain differences in marketing practices between other European countries. Studies of retail marketing with an international dimension need to account for the differences in firm size between the countries that are studied.

No formal mathematical model lies at the basis of our endeavour in the sense that the model employed is explicitly derived from a set of behaviour- 
ial assumptions or that departures from equilibrium are explicitly modelled. No long-run equilibrium is thoroughly discussed. We employ a reduced type model which has been used successfully in earlier studies. We stress comparing and contrasting the empirical results for two different countries, in preference to the one-country study where the modelling is often governed too strictly by typical data opportunities. Empirical evidence becomes convincing when it is valid for different environments, particularly if the model employed is not explicitly derived from formal mathematical modelling.

\section{ACKNOWLEDGEMENTS}

We wish to thank the Institut für Händelsforschung of the University of Cologne and EIM Small Business Research and Consultancy for the provision of the data, and Herman van Schaik for the elaboration of the data.

\section{REFERENCES}

Berry, L.L., L.G. Gresham and N.L. Millikin, 1990, 'Marketing in Retailing: A Research Agenda', International Review of Retail, Distribution and Consumer Research, Vol. 1, pp. 516.

Bode, B., J. Koerts and A.R. Thurik, 1986, 'On Storekeepers' Pricing Behaviour', Journal of Retailing, Vol. 62, No. 1, pp. 98-110.

Cubbin, J.S., 1988, Market Structure and Performance: The Empirical Research, Chur: Harwood Academic Publishers.

Den Hertog, R.G.J., J.C.A. Potjes and A.R. Thurik, 1994, 'Retail Profit Margins in Japan and Germany', Weltwirtschaftliches Archiv, Vol. 130, pp. 375-90.

Den Hertog, R.G.J. and A.R. Thurik, 1992, 'Expectations and Retail Profit Margins', International Review of Retail, Distribution and Consumer Research, Vol. 2, No. 3, pp. 26382.

French, N.D. and R.A. Lynn, 1971, 'Consumer Income and Response to Price Changes: A Shopping Simulation', Journal of Retailing, Vol. 47, No. 4, pp. 21-31.

Hall, M., 1949, Distributive Trading, New York: Hutchinson.

Hall, M., J. Knapp and C. Winsten, 1961, Distribution in Great Britain and North America, London: Oxford University Press.

Judge, G.G., W.E. Griffiths, R.C. Hill, H. Lütkepohl and T.C. Lee, 1988, Introduction to the Theory and Practice of Econometrics, 2nd edition, New York: John Wiley and Sons.

McElroy, B.F. and D.A. Aaker, 1975, 'Unit Pricing Six Years after Introduction', Journal of Retailing, Vol. 55, No. 3, pp. 44-57.

Nooteboom, B., 1985, 'A Mark-up Model of Retail Margins', Applied Economics, Vol. 17, No. 4, pp. 647-67.

Nooteboom, B., 1986, 'Costs, Margins and Competition: Causes of Structural Change in Retailing', International Journal of Research in Marketing, Vol. 3, No. 4, pp. 233-42.

Nooteboom, B., A.J.M. Kleijweg and A.R. Thurik, 1988, 'Normal Costs and Demand Effects in Price Setting: A Study of Retailing', European Economic Review, Vol. 32, No. 3, pp. 999. 1011.

Nooteboom, B. and A.R. Thurik, 1985, 'Retail Margins during Recession and Growth', Economics Letters, Vol. 17, pp. 281-4.

Nooteboom, B., A.R. Thurik and S. Vollebregt, 1986, 'An International Comparison in the 
General Food Trade: Cases of Structural Change', International Journal of Research in Marketing, Vol. 3, No. 4, pp. 241-7.

Nooteboom, B., A.R. Thurik and S. Vollebregt, 1988, 'Do Retail Margins Differ between European Countries? A Comparative Study', in E. Kaynak (ed.), Transnational Retailing, Berlin/New York: Walter de Gruyter.

Ravesloot, T.K. and W.J.P. Vogelesang, 1989, Facts and Figures on Retailing in the Netherlands, Europe and the United States, Zoetermeer: Research Institute for Small and Medium-Sized Business.

Schmalensee, R., 1989, 'Inter-industry Studies of Structure and Performance', in R. Schmalensee and R.D. Willig (eds.), Handbook of Industrial Organization, Amsterdam: Elsevier Science Publishers.

Sundhoff, E. and F. Klein-Blenkers, 1982-87, Mitteilungen des Instituts für Händelsforschung an der Universität zu Köln, Cologne: University of Cologne.

Tellis, G.J., 1987, 'Consumer Purchasing Strategies and the Information in Retail Prices', Journal of Retailing, Vol. 63, No. 3, pp. 279-97.

Thurik, A.R. and W.H.M. van der Hoeven, 1989, 'Manufacturing Margins: Differences between Small and Large Firms', Economics Letters, Vol. 29, pp. 353-9.

Walter, R.G. and H.J. Rinne, 1986, 'An Empirical Investigation into the Impact of Price Promotions on Retail Store Performance', Journal of Retailing, Vol. 62, No. 3, pp. 237-66.

Waterson, M., 1984, Economic Theory of the Industry, Cambridge: Cambridge University Press.

Wilkes, R.E., 1972, 'Consumer Usage of Base Price Information', Journal of Retailing, Vol. 48, No. 4, pp. $72-85$.

Woodside, A.G. and J.T. Sims, 1974, 'Retailing Experiment in Pricing a New Product', Journal of Retailing, Vol. 50, No. 3, pp. 56-65.

\section{NOTES}

1. Leafing through the main journal in this area, The Journal of Retailing, we come across French and Lynn [1971], Wilkes [1972], Woodside and Sims [1974], McElroy and Aaker [1979], Bode, Koerts and Thurik [1986], Walters and Rinne [1986], Tellis [1987], etc.

2. The limited orientation towards retailing is not justified by its limited economic significance. In the European Community (EC-12) the retail trade employs well over 11 million people in about 3.5 million establishments representing a market of approximately 1,000 billion ECU [Ravesloot and Vogelesang, 1989].

3. Den Hertog, Potjes and Thurik [1994] compare Japanese and German retail price setting. In Nooteboom, Thurik and Vollebregt [1988] a comparative study of the retail margins of different European countries is presented. In an earlier study, Nooteboom, Thurik and Vollebregt [1986] made an international comparison of the general food trade between various countries.

4. The margin is defined as the difference between sales and purchase value of sales as a per centage of sales.

5. The model has been used to study the relevance of expectations for retail price setting [Den Hertog and Thurik, 1992], to analyse the Dutch retail margins during recession and growth [Nooteboom and Thurik, 1985], and to examine the influence of normal costs and demand effects on the Dutch retail price setting [Nooteboom, Kleijweg and Thurik, 1988]

6. The operating costs exclude a reward for shopkeepers' labour because this reward is treated as a part of the residual net profit.

7. In the current study we use a 5 per cent significance level.

8. The variable $\mathrm{K}$ accounts for the effect of the higher costs of the service level on the profit margins.

9. Den Hertog, Potjes and Thurik [1992] have compared German and Japanese retail pricing setting, and found similar results. The cautious Japanese shopkeeper tends to pass on more of his operating costs than his German colleague.

10. One US dollar was equal to about 2.5 Dutch guilders and about 2.4 DM in 1976. 